\title{
TIMELINE OF EVENTS
}

Flood Control Act of 1917. Congress takes on federal responsibility for flood control, with the Army Corps of Engineers authorized to oversee flood-control improvements.

Great Mississippi Flood of 1927. Floods 16.5 million acres of land. Prompts private insurance companies to cease flood risk underwriting by 1929 .

Flood Control Act of 1928. Commits federal government to pay for construction of protective measures.

Flood Control Act of 1936. Provides funding for construction, examinations, and surveys of flood control projects. Establishes a national approach to reducing flood damages through engineering projects.

Flood Control Act of 1938. Authorizes new dams, levees, dikes, and other control measures.

Human Adjustment to Floods: A Geographical Approach to the Flood Problem in the United States, geographer Gilbert White's dissertation, argues for nonstructural approaches to reducing flood losses.

Disaster Relief Act of 1950. Establishes first permanent system for disaster relief without need for congressional action. 
1952

1956

1960

1965

1966

1968

(AUGUST)

1968

(DECEMBER)
President Truman pursues flood insurance program. Truman calls for enactment of a federal flood insurance program and proposes legislation to establish a national system of flood disaster insurance.

Federal Flood Insurance Act of 1956. Establishes a direct federal flood insurance program, a federal reinsurance program, and a federal loan contract program covering flood losses, to be run by a new Federal Flood Indemnity Administration (FFIA). These initiatives go unfunded and are eventually abandoned.

Flood Control Act of 1960. Assigns responsibility for producing flood information studies to the Army Corps of Engineers; the Corps is now promoting the use of nonstructural measures.

Southeast Hurricane Disaster Relief Act. Passes in the wake of Hurricane Betsy, which hit the Gulf Coast in September 1965. Mandates that the Department of Housing and Urban Development (HUD) study "alternative permanent programs which could be established to help provide financial assistance in the future to those suffering property losses in floods and other natural disasters, including but not limited to disaster insurance or reinsurance."

Two reports that inform the design of a federal flood insurance program delivered to Congress: Insurance and Other Programs for Financial Assistance to Flood Victims, by HUD, and A Unified National Program for Managing Flood Losses, by a Bureau of the Budget Task Force headed up by Gilbert White.

National Flood Insurance Act of 1968 (Title XIII of the Housing and Urban Development Act of 1968). Authorizes the National Flood Insurance Program (NFIP), a national program to make flood insurance available to occupants of flood-prone areas through cooperation of the federal government and private insurance industry.

National Flood Insurers Association (NFIA) created. Industry flood insurance pool is formed to sell and service NFIP policies. 
1969

(JANUARY)

1969

(JUNE-

AUGUST)

1969

(AUGUST)

1969

(DECEMBER)

1970

1972

1973

1977

1979

1983

NFIP begins operations.

First communities join the NFIP. Communities in Louisiana, Alaska, Virginia, and Mississippi enter the program.

Hurricane Camille hits the Gulf Coast. None of the affected communities are covered by the NFIP.

Housing and Urban Development Act. Authorizes the NFIP to start an emergency program that would provide limited amounts of subsidized insurance to communities before completion of their flood information studies and flood insurance rate maps (FIRMs). Extends deadline for when communities have to comply with floodplain management measures. Extends flood insurance coverage to small businesses.

Disaster Relief Act of 1970. With subsequent amendments, codifies and expands disaster assistance to individuals.

Risk rating changes. The NFIP replaces community risk zones with nationwide risk zones, used for new insurance rate tables.

Flood Disaster Protection Act of 1973. First NFIP reauthorization. Makes the NFIP compulsory for majority of homeowners through addition of mandatory purchase requirement. Provides for grandfathering of subsidized rates. Repeals a provision of the authorizing legislation that had denied disaster relief to persons who could have purchased flood insurance for a year or more but did not do so.

NFIA terminated. Following disagreements between HUD and NFIA, private insurers exit risk-bearing pool in the NFIP. Federal government assumes full operational responsibility for the NFIP.

Federal Emergency Management Agency established. FEMA takes over administration of the NFIP from HUD.

Write-Your-Own program established. Private insurers brought back into the NFIP as fiscal agents of the federal government, marketing, selling, and writing flood insurance policies but bearing no risk. WYO companies receive a commission for this work. 
1983

1994

2005

2007

2009

2011

2012

(JULY)

2012

(OCTOBER)

2013

(JANUARY-

FEBRUARY)

2013

(FEBRUARY)

2013

(JUNE)

2013

(SEPTEMBER)

2013

(DECEMBER)

First FIRMs published for New York City.

National Flood Insurance Reform Act of 1994. Tightens mandatory purchase requirement; codifies Community Rating System; requires review of FIRMs every five years; establishes a Technical Mapping Advisory Council.

Hurricane Katrina. NFIP $\$ 16.1$ billion in debt to U.S. Treasury.

PlaNYC launch. New York City mayor Michael Bloomberg launches coordinated effort to make the city "greener" and "greater." Reports in the following years call on FEMA to update New York City's FIRMs.

FEMA Region II receives funding for FIRM updates in New York and New Jersey.

FEMA Region II begins remapping work.

Biggert-Waters Flood Insurance Reform Act. Mandates gradual phase out of subsidized rates; immediate end of grandfathering; updates to flood insurance rate maps; reconvening of Technical Mapping Advisory Council to advise on incorporating future conditions into maps.

Hurricane Sandy. NFIP is $\$ 24$ billion in debt.

Advisory Base Flood Elevations delivered to Sandy-affected areas. Summarizes available information about flood risk so that residents have best available information for rebuilding. Stop FEMA Now founded by George Kasimos in Toms River, New Jersey.

Preliminary Work Maps delivered to New York City. Maps incorporate more refined wave modeling.

Stop FEMA Now rallies. Protests across ten states on the eve of rate increases mandated by Biggert-Waters.

Preliminary Flood Insurance Rate Maps (pFIRMs) delivered to New York City. Release of the version of the FIRMs that would enter formal adoption phase. Maps show expanded flood zones and higher base flood elevations; almost 400,000 New Yorkers live in the redrawn high-risk flood zones; number of structures inside the zones doubles from around 35,000 to 71,500 . 
2014

(MARCH)

2014

(SEPTEMBER)

2015

(JUNE)

2016

(FEBRUARY)

2016

(OCTOBER)

2018

(APRIL)
Homeowner Flood Insurance Affordability Act passed. Maintains commitment to updated flood risk assessment and mapping; reinstates grandfathering; limits annual rate increases to 18 percent for most homeowners (severe repetitive loss properties can continue to see up to 25 percent increases).

Technical Mapping Advisory Council begins meeting.

New York City pFIRM appeal filed. City argues, on basis of its own risk assessment, that FEMA's models have overestimated water levels by over two feet and unnecessarily mapped 26,00o buildings and 170,000 residents into high-risk zones. Technical Mapping Advisory Council reports published. Indicate that information about future conditions, including conditions related to climate change, should be delivered for advisory purposes.

FEMA and New York City announce two-map solution. One map will show current risk and be used for flood insurance premium rating. The other map of future risk will help the city plan for climate change.

An Affordability Framework for the National Flood Insurance Program report published. Outlines different flood insurance affordability program design options. 
